\title{
Market-based but state-led: The role of public development banks in shaping market-based finance in the European Union
}

\section{Daniel Mertens}

Political Science, Goethe Universitaet Frankfurt am Main, Frankfurt am

Main, Germany

\section{Matthias Thiemann}

Political Science, Centre d'Etudes Europeennes, Paris, France

\begin{abstract}
This paper examines the European Union's strategy of governing the economy through financial markets by focusing on the largely unacknowledged role of public development banks, including the multilateral European Investment Bank. It argues that these state-owned financial institutions have moved into a key position in the recent evolution of the European financial system and economic governance. Since the crisis, policy makers have used them to address the intrinsic volatility and excess liquidity of contemporary financial markets, as well as offset the constraints on public investment imposed by institutionalized fiscal austerity. The paper provides evidence for this claim through an analysis of the emergent policy nexus between the Investment Plan for Europe and the Action Plan on Building a Capital Markets Union. Based on official documents and interview data, it specifically traces the risk-sharing devices for small- and medium-sized enterprise and infrastructure finance set up by development banks within these initiatives. Equipped with public guarantees, they have been instrumental for the promotion of securitization markets and publicprivate partnerships through increased multilevel collaborations among development banks. The anchor role of such quasi-fiscal state actors in shaping capital markets, the paper concludes, has profound political implications, and therefore warrants further scholarly attention.
\end{abstract}




\title{
Keywords
}

Capital Markets Union, development banks, finance-led growth, investment plan for Europe, market-based finance, securitization

\begin{abstract}
'We are making experiences now with the use of the EU budget within in the European Union by shifting from subsidies to guarantees, from grants to loans within the Juncker Plan. [.A]ll these huge objectives we subscribe to ['] can only be financed if we leverage limited public resources and bring private money in.' (Werner Hoyer, EIB president, 25 February 2016) ${ }^{1}$
\end{abstract}

\section{Introduction}

When the European Commission (EC) announced its Action Plan on Building a Capital Markets Union (CMU) (European Commission, 2015d) in 2015, it was heralded as an important step to overcome capital market fragmentation and wean Europe off from a dangerous dependence on bank credit. Based on the re-interpretation of Europe's bankbased systems from a factor of stability to an obstacle to growth (Véron and Wolff, 2016), this initiative was a curious revival of the European Union (EU)'s high praise of capital markets. The lessons of the financial crisis, which had vividly demonstrated the volatility and self-recursive character of market-based credit intermediation, seemed quickly forgotten in the turn to a strategy of 'governing through financial markets' (see Braun and Hubner, 2018 in this issue).

One of the premises of these political attempts to promote capital markets in Europe is that their enhancement is allegedly needed to tackle sluggish economic growth, falling rates of investment and low levels of financial market integration (OECD, 2015: 160). In other words, the current problems plaguing Europe are seen to stem from supply side issues of finance rather than a lack of aggregate demand. The second is that while financial markets are volatile and largely self-referential, these features can supposedly be changed through state intervention, allowing 'resilient' market-based financing to serve the 'real economy' (Hill, 2015). While scholarship has quickly turned to the regulatory implications of these attempts (Dorn, 2016; Friedrich and Thiemann, 2017; Thiemann et al., 2018) and the distribution of political interests behind it (Engelen and Glasmacher, 2018 in this issue; Quaglia et al., 2016), there is relatively little understanding of how these premises and the structural features of the current crisis translate into a specific mode of action, connecting the above challenges with a politico-economic practice of enhancing and stabilizing market-based finance. In other words, how is 'governing through financial markets' set-up and institutionalized in the quest for an investment-oriented integration of financial markets?

This paper proposes to investigate this question by drawing attention to a rarely considered and somewhat 'borderline' actor of financial markets - public development banks which we argue are central to this endeavour. These state-owned financial institutions seldom figure in current investigations of the European political economy, but, we argue, have become crucial nodes in connecting reforms in economic and fiscal governance with the prospect of a CMU. Development banks became visible in the immediate aftermath of the crisis, receiving capital increases and expanding balance sheets to support countercyclical policies. The European Investment Bank (EIB), most remarkably, has grown to become the largest multilateral development bank with assets of roughly 635bn Euro (EUR) in, 2016 - 
rising from 310bn EUR in 2007. Most national development banks (NDBs) have also seen significant increases during the same period, such as Germany's Kreditanstalt fuer Wiederaufbau (KFW) Group, Italy's Cassa Depositi e Prestiti (CDP) and the Instituto de Crédito Oficial (ICO) in Spain. Following a wave of new entrants across the Union, development banks seem to enjoy increasing attention from policy makers, but less so from academic debate (cf. Mertens and Thiemann, 2017).

While there are several historical, organizational and strategic differences between (European) development banks, they all are devised to fulfil politically set tasks, and they all have been included in another signature project of the Juncker Commission, which is vitally linked to the goals of the CMU: The Investment Plan for Europe. This 'Juncker Plan' - first communicated in November 2014 - and its core piece European Fund for Strategic Investment (EFSI) aim at increasing investment in the 'real economy' by both mobilizing private funds and leveraging limited public funds (European Commission, 2014). These initiatives have repeatedly highlighted the importance of development banks for the success of the plan, both throughout its negotiation and implementation. In July 2015, the EC even published a communication on the 'role of national promotional banks in supporting the Investment Plan for Europe' (European Commission, 2015b). ${ }^{2}$ Most importantly, the Investment Plan was launched jointly by the EC and the EIB, with the latter in full operational control.

The linkages between the CMU action plan and the Investment Plan for Europe can be found in the political propositions of financing small- and medium-sized enterprises (SMEs) and infrastructure through debt and equity products as well as the revival of securitization markets that seeks to transform bank loans into capital market products. In this sense, these initiatives are both instances of the promotion and stabilization of market-based finance that is at the heart of deepening and integrating European financial markets. However, while the CMU action plan is mainly concerned with regulatory reforms, the Investment Plan creates a coalition of supranational institutions, national governments, development banks and private financial actors, developing and supporting the new financial opportunity spaces created by regulatory changes. In its wake, we are witnessing a reconfiguration of statefinance relations in which development banks become anchor investors ${ }^{3}$ for volatile capital markets, absorbing idiosyncratic as well as conjunctural risks to channel self-recursive finance into the 'real economy'. This paper thus contends that development banks are moving into a key position in the EU's strategy to govern through financial markets, seeking to restore aggregate demand and productivity growth through the leverage of public funds and the development of SME loans and infrastructure investment as new asset classes for institutional investors.

To substantiate this argument, the paper proceeds as follows. We first discuss the current role of development banks by engaging with two conjunctural features of contemporary capitalism: (1) the rise of market-based finance and financial market volatility and (2) the rise of the 'consolidation state' through institutionalized austerity. Here, we introduce the concepts of market-shaping and off-balance sheet policy making to provide a conceptual framework for the state-led enabling of market-based finance through development banks (section 2). Against this background, we then move on to the substance of current European policy making and delineate the emergent nexus between CMU and EFSI through an analysis of EU regulations and communications (section 3). The empirical analyses of the market-shaping and risk-sharing activities pursued by European development banks within this nexus follow in sections 4 and 5. Building on the two main areas of 
concern in the CMU-EFSI nexus, infrastructure and SME finance, we provide evidence for how development banks attempt to channel institutional investor's funds into the 'real economy'. Using data from official European sources as well as 11 interviews with policy makers and development bankers, ${ }^{4}$ we trace their role in the risk-sharing constructs for funding infrastructure (section 4) and in the securitization of SME loans (section 5), revealing their widely unacknowledged institutional work in shaping market-based credit intermediation.

It will become clear that the current strategy of governing through financial markets in the EU employs constrained public funds as well as the radiance of anchor investments by public institutions to steer market-based finance. Our analysis shows that the involvement of development banks with market-based finance in the wake of the Juncker Plan might be able to address some shortcomings of non-bank lending while sparing deficit spending, but in turn requires the state to engage as a technocratic risk manager, whose investment policy becomes increasingly more dependent on investor consent than democratic control. We therefore conclude with a discussion of the political implications stemming from our perspective on governing through financial markets by means of development banking in Europe.

\section{Conceptualizing the role of development banks in contemporary capitalism}

How can we make sense of the current role of development banking in the European political economy? In this section, we focus on two features of contemporary capitalism that strike us as useful vantage points. The first encompasses the larger transformations and shortcomings - in banking and credit intermediation that have been associated with the rise of financialization. Here, scholars have stressed the 'disintermediation' of loan business and the diffusion of shareholder value in determining banks' strategies (e.g. Engelen et al., 2011; Konings, 2011). In this context, Hardie et al., (2013) have pointed to the emergence of a market-based model of bank business that has been obfuscated by the traditional distinction between the broadly European bank-based systems and its liberal capital market counterparts (Zysman, 1983). They essentially contend that over the past 30 years and across numerous countries, banks have increasingly relied on global financial markets to fund their lending activities to non-financial corporations (or the 'real economy'). By making use of derivatives, securitization and mark-to-market accounting, banks have become more prone to market volatility, substantially undermining their ability to provide long-term financing ('patient capital') (Hardie et al., 2013: 696).

An intricate feature of this transformation of banking and the global financial system has been the rise of shadow banking, which through regulatory interventions is now to become a system of 'resilient market-based finance' (G20, 2017: 7). This rhetorical shift acknowledges that such forms of financing are intrinsically volatile, but also that the institutional work required to make them resilient can deliver benefits to the economy. In this understanding, market-based finance, which involves, in the words of the European Central Bank (ECB) president, 'non-bank lending, such as equity and bond markets, securitization, lending from insurance companies and asset managers, venture capital and crowdfunding' (Draghi, 2014), is supposed to deliver an additional financing channel for the 'real economy' in Europe, which is seen as too dependent on bank financing (Langfield and Pagano, 2016). 
By expanding capital market financing, in particular securitization, the new mix is supposed to deliver a more stable financial system, which according to official language would allow Europe to achieve its full growth potential (European Commission, 2017b).

This pro-growth discourse assumes that pre-crisis abuse of securitization as a risk-shifting rather than a risk-sharing device (Acharya et al., 2009) can be overcome through STS regulation (see Engelen and Glasmacher, 2018; Hübner, 2016), which ensures due diligence by investors and transparency, allowing markets to properly price risks. It further entails the idea that capital markets have the potential to provide 'patient capital' but have increasingly failed to do so (Deeg et al., 2016).

We contend that the entry of state-owned development banks in these analyses helps to better understand the work by state actors to harness these new financing channels for the 'real economy' and thereby reap the alleged benefits of market-based finance. Development banks have not figured greatly in studies of financialization and financial systems, mainly because they seemed to belong to a Gerschenkronian past of economic backwardness - at least in the core economies (see Verdier, 2000). With the recent crisis, development banks have been pushed by policy makers and academics alike as countervailing forces against the poor investment score and severe crises associated with financialization (cf. Mazzucato and Penna, 2016; also Griffith-Jones and Cozzi, 2016; Kollatz-Ahnen, 2015). With a track record in long-term financing and financial strength through political-institutional weight and preferred creditor status, ${ }^{6}$ many have seen them as (political and financial) institutions that may realign growth with financial systems stabilization. Indeed, we may recall Zysman's (1983) original contention that in some contexts 'government's role is to compensate for weaknesses in an existing private financial system', blurring the borderline between public and private when shaping the structure of financial markets (Zysman, 1983: 72).

Doing so in the context of the Juncker Plan and the plan to build a CMU, development banks seem to acquire a role that goes beyond their market-correcting countercyclical efforts. In a conceptual piece, Mazzucato and Penna (2016) have indeed pointed to the fact that what development banks do about innovation and capital development is often market-shaping and market-creating, i.e. they address societal challenges by building a functional ecosystem that channels financial flows. The study of development banks, in this sense, is making a case for Polanyi's (1944) argument that understanding the evolution of capitalist societies requires attention to the political constitution of markets.

This is no less important under the second feature of contemporary capitalism we conceptually link European development banks to - the rise of what Streeck (2015) has called the 'European consolidation state'. It follows from a gradual institutionalization of fiscal austerity at the European level that involves the deficit and debt criteria of the Maastricht Treaty in the early 1990s as well as the post-crisis reforms intended to impose fiscal discipline on EU member states, such as the Fiscal Compact and the so-called Six-pack (see also Verdun, 2015). As a result, member states have committed themselves to the goal of balanced budgets, sometimes by constitutional norm, effectively subjecting their economic policy leeway to a set of institutions that let fiscal consolidation rule supreme. An interview on 27 May 2016 with a former European Commission official participating in the negotiations confirmed that the widespread concerns over falling investment have not been strong enough to fundamentally weaken these imperatives, yet the Investment Plan for Europe was clearly negotiated against the background of member states' unwillingness or inability to provide additional public funds to confront the crisis. 
Another official from EIB with long-term experience reminded during an interview in August 2016 that development banks have traditionally been welcome means for policy makers to offset such constraints on government spending and served as vehicles for what we call 'off-balance sheet policy making'. Here, economic and social policies are pursued by quasi-fiscal institutions whose costs only materialize in public budgets in the case of severe crisis and risk exposure (cf. Mertens, 2017; Quinn, 2017). This means that besides defining the policy goals, the primary task for the state in such constructions is to manage this risk (Moss, 2002). However, development banks' role in preventing a further strain of public balance sheets through extending credit, subsidies and grants has arguably become more important through crisis-led fiscal integration. In this sense, the initial quote by the current EIB president Hoyer signals the overriding impetus of 'doing more with less' that resonates with the doctrine of 'new public management' and budgetary efficiency (Hood, 1991). The recent case of founding the Green Investment Bank in the UK as a new developmental institution displays a similar reasoning. Here, the House of Commons (2011: 3) stated that the 'Government's top priority is to cut the deficit, so investment will have to come predominantly from the private sector. A Green Investment Bank will be an essential means of unlocking the enormous scale of private sector investment needed'.

In contrast to the post-war model of subsidized loans and grants through development banks, these quotes suggest a qualitative difference in the new role these institutions carry within Europe, which is mobilizing private funds not only for their own refinancing but also for the very projects they promote - with the help of guarantees from public budgets. Correspondingly, Streeck (2015) has suggested that in European consolidation states, the prime solution to fiscal constraints imposed by 'debt ceilings' is public-private partnership (PPP). ${ }^{7}$ Although development banks have played an increasing role in such arrangements already since the early 2000s, which include so-called private finance initiatives (PFIs) and joint finance agreements (OECD, 2014), the political initiatives we delineate below seem to have institutionalized this linkage between austerity and public bank-based PPPs in Europe.

The firm position of fiscal consolidation as an overriding policy goal in post-crisis Europe is, however, intricately linked with other conjunctural features that relate back to the rise of market-based finance. Importantly, as the sovereign debt crisis has fuelled a crisis of 'safe assets' (see Gabor and Vestergaard, 2018, in this issue), it has also disrupted a key business model for institutional investors such as insurances and pension funds. Both the risks and the returns associated with European sovereign bond markets after the crisis have increased these investors' difficulties to deliver contractually secured payments on their liabilities to households and companies (Joint Committee of the European Supervisory Authorities, 2017). Yet the policies pursued by the ECB over the past few years have heavily exacerbated these difficulties, which have been instrumental to lower interest rates and thereby yields for government bonds. Interestingly, the high level of liquidity in financial markets that is associated with this entanglement has fuelled asset price inflation rather than translating into investment (Acharya et al., 2017). ${ }^{8}$

It is against this background that financial system stabilization has become a prime goal of post-crisis policy making (Baker and Murphy, 2016), and we would like to suggest that these concerns are the final element that motivates the envisaged new role of development banks, i.e. being an institutional fix to both fiscal and capital market incapacities to bolster investment across the Union. This, at least, is the framework we offer for approaching the emergent nexus of CMU and EFSI, to which we turn in the next section. 


\section{The CMU-EFSI nexus}

The contention of this paper is that the plan for building a CMU and the Juncker Plan with its core piece EFSI are the political projects in which this new role of development banks to shape market-based finance in the EU, seeking to achieve public policy purposes off-balance sheet, comes to life. Therefore, this section is concerned with laying bare the substance of what we call the CMU-EFSI nexus.

In this nexus, development banks' tasks are especially to reduce Europe's reliance on bank credit (CMU) and increase private investment through public guarantees (EFSI). In the words of the Commission:

'The combination of public finance, such as EFSI, with enabling regulatory reform is an enlightened strategy. Public finance can accelerate change by building market experience, conventions and systems. It can help to overcome structural barriers that limit the geographic reach of capital markets'. (European Commission, 2017a)

This quote highlights the nexus as a combination of regulatory and fiscal tools, in which the latter are under management of development banks to build the infrastructure for a European capital market. Facilitating 'market experience, conventions and systems' aims at allowing non-bank finance to supplement bank credit, while also freeing up banks' balance sheets through enabling securitization.

The EFSI is the most prominent pillar of the Investment Plan for Europe. In the initial set up, it entailed a combined guarantee of 16bn EUR from the EU budget and 5bn EUR from the EIB to allow the EIB and its subsidiary, the European Investment Fund (EIF), to provide $63 \mathrm{bn}$ EUR of capital (leverage of 1:3). This 63bn EUR funding is planned to be employed to mobilize private and public investment of $315 \mathrm{bn}$ EUR in total (leverage of 1:5) for long-term investments (e.g. in infrastructure) and the financing of SMEs (and so-called mid-caps). In December 2017, the European Parliament approved to expand the EU budget guarantee to 26bn EUR, in combination with an increase in the EIB's contribution to $7.5 \mathrm{bn}$ EUR to lead to total investment of $500 \mathrm{bn}$ EUR by 2020. The other two pillars of the Investment Plan encompass the European Investment Advisory Hub (EIAH) and the European Investment Project Portal (EIPP) that are supposed to offer advisory and information services to increase investor participation, 'making finance reach the real economy' (European Union, 2015). Development banks contribute to all three pillars of the Investment Plan: first through financial contributions, co-financing of projects and risksharing with other development banks and private investors (EFSI); second through providing the (technical) expertise for project selection as well as its financing, planning and implementation within the EIAH ${ }^{9}$ and third through supporting and registering at the EIPP to connect project promoters and investors (European Commission, 2015b).

Figure 1 summarizes the CMU-EFSI policy nexus. It is key to understand that in 'creating an investment friendly environment', the Investment Plan is supposed to 'include progress towards capital markets union' to complement the policy goals of 'structural reform' and 'growth-friendly consolidation', which is summarized under box 3 of the figure (European Commission, 2014). Development banks, as mentioned in box 1 and contributing to box 2, are supposed to serve the CMU goal of deeper and more integrated capital markets through specifically targeting its three objectives of (1) providing companies 


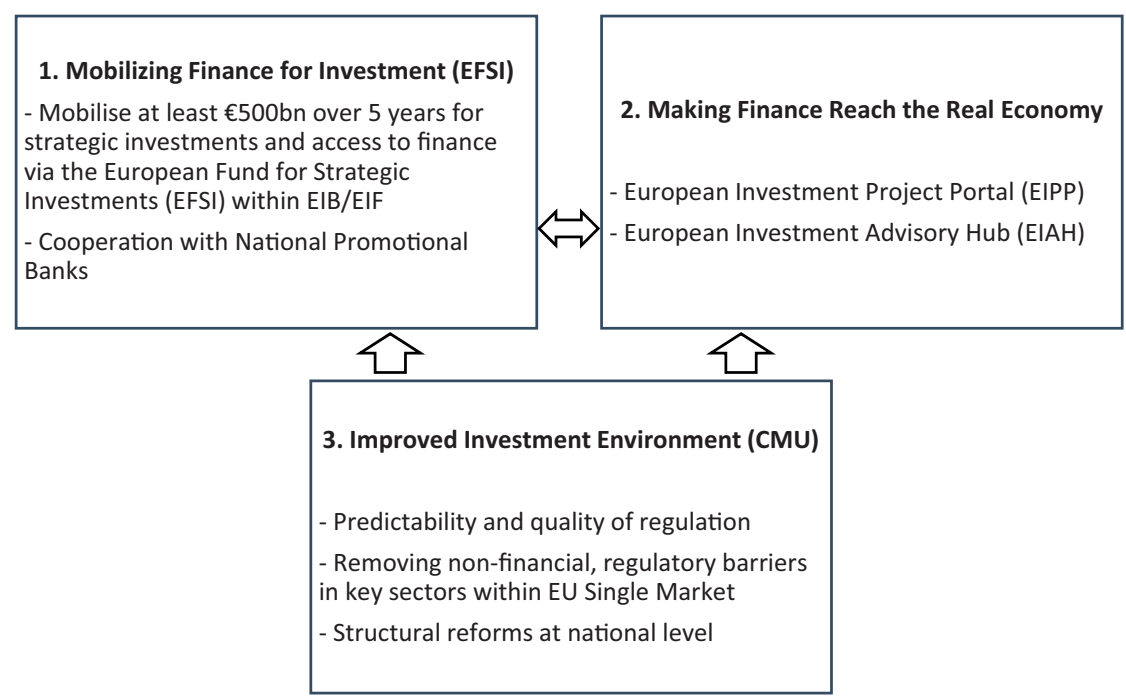

Figure I. The Investment Plan for Europe as CMU-EFSI policy nexus. Source: own adaptation from EFSI Steering Board.

CMU: Capital Markets Union; EIB: European Investment Bank; EFSI: European Fund for Strategic Investment; EIF: European Investment Fund; EU: European Union.

with lower cost and greater choice of funding; (2) offering new opportunities for investors and (3) increasing financial stability. ${ }^{10}$

For instance, the regulation for the EFSI stipulates that:

'Many SMEs and mid-cap companies across the Union require assistance to attract market financing, especially as regards investments that carry a higher degree of risk. The EFSI should help those entities to overcome capital shortages, market failures and financial fragmentation resulting in an uneven playing field across the Union by allowing the EIB and the European Investment Fund (EIF) and national promotional banks or institutions, investment platforms or funds to provide direct and indirect equity injections, as well as to provide guarantees for highquality securitisation of loans.' (European Union, 2015: 5)

It has repeatedly been noted that the CMU rhetoric of putting SMEs centre stage had been something like a smoke screen of the initiating commissioner Hill (see e.g. Dorn, 2016), yet development banks from France, Germany, Italy and Spain have embraced this task as one of their fundamental contributions to these policy initiatives (BPI et al., 2015).

Furthermore, providing profitable opportunities to investors features prominently in both plans, resonating well with the conjectural challenges posed by the rise of marketbased finance and fiscal austerity. As the EFSI regulation spells out, 'infrastructure project finance can be seen as a means of diversifying institutional investors' asset portfolios' (European Union, 2015: 7), while at the same time, as an EIB working paper notes, 'there is scope for an increased contribution from alternative financing arrangements, especially PPPs, and for the development of capital markets and instruments such as project bonds and suitable funds. Institutional investors can play an increasing role but there are investment barriers that need to be recognised and addressed' (Inderst, 2013: 23). ${ }^{11}$ 
Key informant interviews with a former EC official on 27 May 2016 and a former EIB official on 29 September 2016 indicated that the role and expertise that is attributed to development banks have led European policy makers to see the EIB and NDBs as a "natural partner' through the negotiations of these plans. First, by setting up programs to facilitate private investment, they can to some extent relief public budgets from the burden of fiscal stimulus. With EFSI, the main differences to direct spending and tax cuts are (a) the leverage ratio, aiming for a 1:15 leverage of public funds and (b) the use of loans and guarantees, ideally leading to revolving funds for these banks. Second, development banks' broad spectrum of financial instruments and project expertise seems crucial to offer investment opportunities, creating new asset classes for institutional investors, which are 'safe' but yield higher return than government bonds.

This implies a need to predict, and if necessary guarantee expected fee income from investment projects, limiting the scope of projects to those that can be made subject to user fees (so-called toll goods, ${ }^{12}$ such as highways with fee systems). These fee payments are to be transformed into allotted interest payments on tranches of securitization, which are then to garner investments from large professional investors. Here, the technical expertise ascribed to development banks unfold as envisaged by the EFSI's complementary pillars of the EIAH and the EIPP. ${ }^{13}$ However, to assess the potential political implications of this nexus, we must first understand the key risk-sharing devices that development banks have created regarding EFSI and CMU. For this reason, we now turn to examine development bank activity in the Juncker Plan. Using EFSI's publicly accessible project database with information on funded projects, project volumes and participant investors since 2015, we point to the significant expansion of PPPs and the multilevel use of financial engineering to shape European capital markets. Subsequently, we trace the largely unacknowledged role of development banks in establishing securitization markets in Europe mainly but not exclusively for SMEs, regarding both lobbying for regulatory changes and implementing new schemes.

\section{Development banks' financial engineering in the CMU-EFSI nexus}

Since its initiation, the Juncker Plan has seen many assessments from political parties, think tanks and academic scholarship, which have mainly addressed questions of additionality (projects have to be 'additional' in the sense that they do not 'crowd out' private investments), the governance and transparency of the EFSI, its economic and environmental impact and the geographical and sectoral distribution of projects (Ban and Seabrooke, 2016; Counter Balance, 2015; Rubio et al., 2016; Wruuck, 2016). This debate has generated important discussion and criticisms, but it seems agnostic to the fact that the Investment Plan is supposed to become effective through a 'wide range of financial products, including equity, debt and guarantees' and 'act as a catalyst for private finance' (European Union, 2015: 5).

At the same time, the Investment Plan echoes the idea that the financial sector requires an industrial policy for its competitiveness (Helleiner, 1994: 160) - and stability - and pays tribute to the fact that financialization has altered the way economic policy operates (Palley, 2013). According to the Commission, 'EFSI will - as a rule - provide the riskier tranche of the investment to maximise the contribution from private sources of financing by taking risk out of the equation ("first loss protection")' (European Commission, 2015a), enabling favourable conditions for investors. This rule applies to EFSI-operations in the narrower 
sense as well as to related activities based on cooperation between NDBs and the EIB's EIF. ${ }^{14}$ Since this paper contends that these serve as the material basis for shaping (and stabilizing) market-based finance, it is worth examining the respective risk-sharing devices as key features of governing through financial markets.

In short, the EFSI works through the combination of public guarantees, co-financing and acquisition of first loss-tranches. Through them development banks leverage funds, support larger and assumingly riskier projects and reduce the risk for investors. For example, one can imagine an infrastructure project such as a motorway construction, with an estimated cost of $15 \mathrm{~m}$ EUR with different risk tranches for private investors to participate in equity or debt. In either case, a schematic involvement would see $3 \mathrm{~m}$ EUR coming from the EIB, providing a guarantee; a NDB, backed by a European guarantee, would contribute another $3 \mathrm{~m}$ EUR taking and finally, private investors who are supposed to mobilize the remaining 9m EUR (Figure 2).

For this to work, it is crucial that there is a sound selection of fee generating and profitable projects, which is what the EIB and NDBs are supposed to do in the Plan's project portal and through the advisory hub. In short, with EU funds for credit protection at their back, EIB and NDBs are expected to provide profitable investment opportunities to 'institutional investors in the EU and abroad', ${ }^{15}$ with public funds taking the highest risks.

The key risk-sharing devices under the EFSIs are (1) the EIB-managed schemes that offer longer-term senior debt for higher risk projects, subordinated loans and equity investment; ${ }^{16}$ (2) the EIF-managed equity schemes and (3) the EIF-managed guarantee schemes. ${ }^{17}$ Funding is either devoted to the so-called 'infrastructure and innovation window' (initially estimated 275bn of investment) or to the SME window (estimated 75bn). As of 14 November 2017, 49.6bn EUR of EFSI financing was approved to mobilize investments of 251.6bn EUR with the EIB accounting for $38 \mathrm{bn}$ EUR and the EIF for 11.6bn. At this time, roughly $30 \%$ of the investment has targeted small enterprises in both investment windows. So how does the CMU-EFSI policy nexus work in practice? Given the enormous technical variety in financial engineering and instruments under EIB and EIF activity, the remainder of this section presents an illustrative cut-out of the operations based on public-private risksharing devices.

The set-up under the EIB-managed schemes draws in many instances on the co-financing schemes after the crisis, such as the Europe, 2020 Project Bond Initiative by the Commission and the EIB, which was already supposed to 'stimulate capital market financing for large-

\begin{tabular}{|c|c|}
\hline Private investors: $\mathbf{9 m}$ & Senior Tranche \\
\hline $\begin{array}{l}\text { National Development } \\
\text { Bank: } \mathbf{3 m}\end{array}$ & Mezzanine Tranche \\
\hline $\begin{array}{l}\text { European Investment } \\
\text { Bank: } \mathbf{3 m}\end{array}$ & $\begin{array}{l}\text {,First-loss' (Junior) } \\
\text { Tranche }\end{array}$ \\
\hline
\end{tabular}

Figure 2. Waterfall principle of risk allocation in the funding of PPPs.

PPP: public-private partnership. 
scale infrastructure' through credit enhancements and an expansion of such PPPs. This means, that the project promoter (a public authority, an investment fund or an investment consortium, for instance) receives EIB financing that 'underlies the senior debt and therefore improves its credit quality, offering peace of mind to institutional investors' (own emphasis). ${ }^{18}$ The value added by EFSI is the extended guarantee from the EU budget, which the EIB can use to reduce risk for outside investors and thereby increase leverage. The EIB can do so alone, but with the EFSI also through a multilevel structure that can involve EU structural funds and, crucially, national (and sometimes regional) development institutions. In this way, EFSI works as a guarantee facility and a giant PPP for a variety of projects ranging from transport, R\&D and housing to the energy sector.

A special instrument in the EFSI that is supposed to promulgate actor coalitions around development banking and envisaged to harness investment and market-based finance are socalled investment platforms. According to EU regulation, investment platforms are 'special purpose vehicles, managed accounts, contract-based co-financing or risk-sharing arrangements [-] by which entities channel a financial contribution to finance a number of investment projects' (European Union, 2015: 10). This means they are supposed to bundle projects that cross borders and/or are too small to usually attract non-bank finance. Furthermore, as special purpose vehicles they facilitate the risk-sharing between different private and public entities, in which national or regional development banks can use the EU guarantee facility to obtain or cover the junior and mezzanine tranches, while the senior tranches are reserved for private (institutional) investors (also see Figure 2).

Accordingly, a development bank can be the prime promoter of a project, as is the case in the Spanish ICO's risk-sharing platforms for SMEs and infrastructure financing. Here, ICO either shares equity risk with the EIB or uses credit lines for its subsidiary fund to revitalize the private equity market in Spain. ${ }^{19}$ In other cases, development banks are one of several public and corporate promoters, which share the risk for specific investments (for instance in the French Overseas Territories Economic Development platform). Finally, there is the case of the Italian CDP, which has set-up an investment platform that provides 'risk-sharing instruments to participating Italian financial institutions on portfolios of senior loans to SMEs with large investment projects and mid-caps. This investment platform is expected to improve the access to finance of Italian SMEs (with investments above EUR 7.5m) and midcaps and encourage investments' (CDP IP MIDCAPS, 14 November 2016). ${ }^{20}$

In July 2017, platforms accounted for at least 1.5bn EUR of EFSI financing with a large participation of development banks, underlining what the Commission had communicated in 2015 on their role in the Plan:

\footnotetext{
'With public institutions acting as anchor investors and independent management, investment platforms have the potential to attract investment from institutional investors and, possibly, sovereign wealth funds at a significant scale. Where necessary, credit enhancement can be provided from EFSI to facilitate the entry of private co-investors by mitigating specific project or portfolio risks'. (European Commission, 2015b: 10)
}

Beyond these project schemes, EFSI also offers credit protection for loans, guarantees and equity investment for SMEs and mid-caps granted by the EIF to financial intermediaries, mostly development banks or commercial banks (guarantees), as well as funds and funds of funds (equity). In this sense, the nurturing of non-bank lending goes hand in hand with the stabilization of the traditional bank lending channels. Through its existing programs for risk 
financing, which are in part boosted by the Investment Plan, these schemes materially tackle several goals envisaged by the CMU action plan, such as financing for innovation and startups, strengthening the capacity of capital markets and facilitating cross-border investments.

The goal to harmonize Europe's capital markets is further pursued with the help of development banks across the Union through 'the EIF-NPI Equity Investment Platform, a non-binding governance framework,' in which the 'EIF offers the possibility for National Promotional Institutions to match the total budget of investments under the EFSI SME Window on a 1:1 basis.' Here, EIF and development institutions coordinate their strategies to catalyse private investments into the private equity and venture capital market, but also for social impact investments. ${ }^{21}$

Finally, the guarantee schemes under EIF management intend to extend loans to companies by allocating some of the credit risk to its balance sheet and the EU budget. Again, EIF activity can build on existing guarantee facilities, namely COSME and InnovFin, under which losses incurred by private commercial banks, asset management firms and development institutions are covered up to $7.5 \mathrm{~m}$ EUR. Assuming the largest chunk of risks of SME lending through direct and counter guarantees, EFSI and the EIF pursue two goals at once: making lending to SMEs attractive for banks, who will find it less risky and more profitable than without the guarantees, and ensuring credit provision for SMEs and mid-caps, who otherwise might struggle for financing. This strategy obviously has some pitfalls, as it implies the reallocation of credit risks to the public. For this reason, the EFSI must ensure that the intermediaries employ sound creditworthiness evaluations, which is why development banks such as the Polish Bank Gospodarstwa Krajowego (BGK), the Italian CDP, the Croatian Hrvatska banka za obnovu i razvita (HBOR) and the newly created Irish Strategic Banking Corporation of Ireland (SBCI) figure prominently in this scheme. ${ }^{22}$

The depicted schemes clearly show how the EIB and the EIF in cooperation with NDBs engage in the reconfiguration of the European capital markets and shadow banking system. Crucially, this envisaged state-led stabilization of the financial system builds on the guarantees provided by the EU budget. Since both EIB and EIF use capital markets (and their preferential rating) for the expansion of these activities, these programs are also indirectly part of the EFSI-based manufacturing of safe assets. However, from the analysis of the EIBmanaged schemes, it is hard to assess the magnitude by which non-banks have joined in terms of volume. Clearly, the construction of such state guarantees, which involves the projection of future cash flow generated by the SME and infrastructure projects they finance, holds risk for both institutional investors and public budgets. This is particularly salient in infrastructure finance.

First of all, trying to tap capital markets for such funding always requires policy makers to provide a risk-and-return construction that appeals to investors, infringing on the discretionary policy space for public investment. Such a construction further entails calculations on the predicted use of infrastructure projects. Should these projections turn out to be wrong, either side may stand to lose - but particularly the one who is contracted to take the first loss.

Experiences with a feeder road surrounding Milan and a highway construction project in Germany appear instructive in this regard. In both cases, the calculation of traffic volumes based on pre-financial crisis growth assumptions was overly optimistic, which meant that the returns private investors were promised at the outset could not be realized. Whereas in Italy, according to one of our key informants from KFW, investors had to accept lower returns, leading private investors to shun these projects. Similar miscalculations in the German case led to a lawsuit, in which private investors demand in total a sum of more 
than 600m Euros from the German government (Balser, 2017). As these examples show, these risk-sharing agreements for infrastructure projects, based on extrapolations of current trends can easily 'misfire' (Callon, 2010: 164), leading to the realization of unexpected losses, pushed onto the government under risk-sharing arrangements. This is no less true for the promotion of SME securitization, to which we turn in the next section.

\section{Development banks in the politics of securitization}

The preceding sections have made clear that development banks have taken a seminal position in the CMU-EFSI nexus and that one of their key operational activities in the context of the Juncker Plan is to strengthen the market for asset-backed securities (ABS), in particular for SMEs. It is worth discussing this dimension of development bank activity since this technique of securitization, according to the plans for CMU, is supposed to serve as a central solution to the challenges the current historical conjuncture poses (European Commission, 2015d). It aims to free up the balance sheets of banks and foster access to finance for SMEs, while at the same time creating assets for institutional investors that display a greater need for safe, but higher-yielding, investment. These goals coalesce around the project of SME securitization, where the EIB, the EIF, as well as a network of NDBs engage to revive it.

In doing so, development banks combine a focus on SMEs with synthetic securitization techniques to achieve capital relief for commercial banks, not merely refinancing (Véron and Wolff, 2016: 139f.). The increased access to non-bank finance for SMEs is an explicit part of the CMU plan and development banks' actively aligned with this focus (Kraemer-Eis et al., 2015: 35ff.). Furthermore, a point, which was underscored by the officials from both the KFW and the EIF, was that leading development banks, such as the EIB and KFW, have been pushing jointly with the European Banking Authority for the inclusion of these techniques in the framework for STS securitization, a cornerstone of the CMU initiative. ${ }^{23}$

In contrast to the United States, where government-sponsored enterprises have engaged in building a market for mortgage-backed securities since the 1960s (Quinn, 2017), European development banks did not play such a central role in the introduction of new securitization techniques for mortgage markets. However, from the 1990s onwards, NDBs in several countries (most notably Germany and Spain) started to promote securitization techniques with respect to SME loans. Furthermore, on the European level, the EIF came to actively support the development of this market (Ranne, 2005). The EFSI securitization initiative is based upon this development bank-driven project of SME securitization precrisis. Back then, just as today, the argument advanced by these development institutions was that without public support, the segment of the market would remain underdeveloped, as information asymmetries and high transaction costs would lead to persistent market failures. In contrast, standardization as well as an increase in volume brought about by the involvement of public actors might facilitate market development (Ranne, 2005: 53).

Started in 1998, the securitization of SME loans in Europe would reach 7\% of the overall securitization volume in 2004 (Ranne, 2005) and the total volume of SME securitizations exceeded the US by a factor of six (European Commission, 2004: 1). However, more than $60 \%$ of these transactions involved either the German KFW via its securitization program or the Spanish Fondos de Titulización para financiación PYME (FTYPME), a securitization fund for SMEs, illustrating the dependence of the market on public intervention. Even then, providing capital relief was a primary goal of development banks' securitization 
activities, fearing the negative impact the new ratings-based approach embedded in Basel II might have on SME lending. For this reason, synthetic securitization activities, which only seek to transfer risk but do not address funding needs, were the preferred technique of NDBs. ${ }^{24}$ Such credit risk transfer and capital relief are further facilitated by the zero-risk weighting assigned to the assets guaranteed by the development banks' triple A rating and/ or their designation as multilateral development banks, which permits a zero-risk weighting for counterparty risk (European Commission, 2004: 37; Kraemer-Eis et al., 2015: 22).

The first synthetic transaction of SME loans was offered by the PROMISE program of KFW, initiated in 1999, which used credit default guarantees to synthetically securitize SME loans and thereby provide commercial banks with capital relief. KFW pursued European ambitions with this platform, offering its services also in other European countries and by 2004, 20\% of securitization activities by PROMISE applied to transactions abroad (Ranne, 2005: 52), with further expansion planned. A study commissioned by the European Commission in 2004 applauded the positive impact development banks had had as catalysts for the market in terms of standardization and investment. It suggested that, to facilitate further growth, these institutions should be permitted to 'take more aggressive risk positions'. The funding for this increased engagement was to come from public budgets (European Commission, 2004: 5), anticipating the Juncker Plan. However, a greater use of this platform on the European scale and the use of public funds were inhibited by the Financial Crisis. ${ }^{25}$ It was for the EIB group in conjunction with NDBs to take up the ambitious European wide program to bolster securitization envisioned by KFW in the context of the Investment Plan from 2015 onwards.

Since the financial crisis, the market for securitized SME loans had largely lost its lustre as well as its function of credit risk transfer (Kraemer-Eis et al., 2015: 15). Arguing for the need for intervention due to a massive market failure based on information asymmetries and high transaction costs, the EIF had already expanded its involvement in the securitization market strongly from 2013 (for this and the following see Kraemer-Eis et al., 2015: 22; Kraemer-Eis et al., 2013). However, as the EIF pointed out, to overcome the risk constraints of public actors and to compensate for the lack of reliable private investors, additional European funds were needed. These funds were to be provided in the context of the EFSI. ${ }^{26}$ Having received such funding, the EIB, the EIF and NDBs seek to re-establish an actual market for SME securitization to achieve capital relief for large banking groups to facilitate further SME lending. In these schemes, the EIF grants guarantee to mezzanine tranches of SME securitizations to make such products attractive to investors, while the EIB and NDBs act as investor in mezzanine and senior notes of such issuance (Figure 3).

The latest institutional step to increase the capacity of European development banks to support and revive the securitization market for SME securitization is the creation of a joint EIF-NPI securitization platform (ENSI), which brings together seven national development institutions to act as main investors in senior and mezzanine tranches in the scheme depicted in Figure 3 (BBB et al., 2016). Both KFW and EIF officials maintained that this platform is likely to permit an increase of the volume of SME securitization on the European level by streamlining the investment process and bundling the expertise, know how, local connections, and capacities of these different institutions. Subsequently, by end of 2016, the EIF and EIB, joined by NDBs, had already used $84 \%$ of the EFSI window related to SME financing. ${ }^{27}$

Only time will show whether this institutional work by development banks can overcome the information asymmetries in SME loan securitization. Some development bankers 


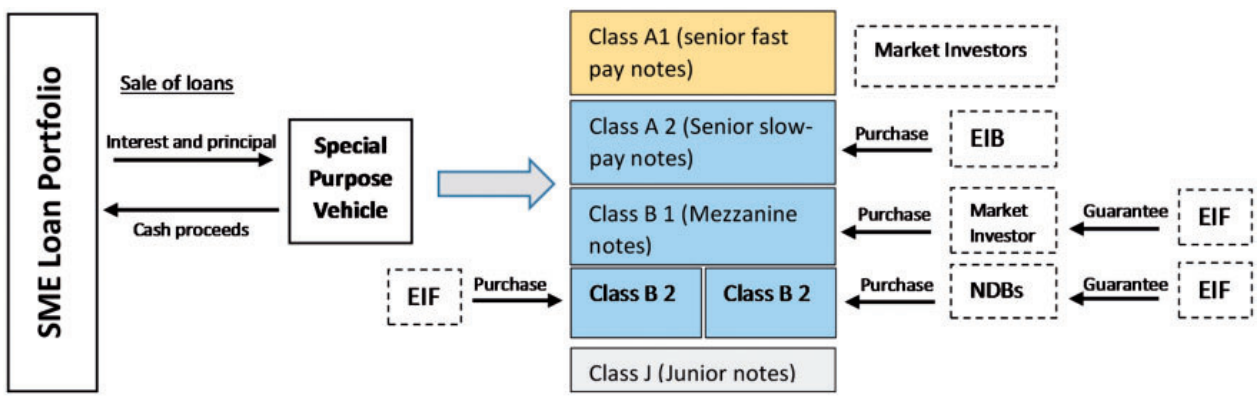

Figure 3. Development banks promoting SME securitization.

Source: authors' adaptation from BBB et al., (2016) and Kraemer-Eis et al. (20I5).

EIB: European Investment Bank; EIF: European Investment Fund; SME: small- and medium-sized enterprises.

involved in the pre-crisis attempt doubt whether such achievements are possible, as commercial banks have an information advantage they will continue to exploit. Whether or not development bankers will have the ingenuity and the capacity for institutional innovations to deal with this asymmetry will determine whether SME securitization will be used by commercial banks to off-load loans they no longer deem viable, depleting guarantees by NDBs and EU budgetary sources. Weighing these risks and the potential benefits leads us to consider the larger implications of this shift towards state-led market-based finance.

\section{Conclusions}

The contemporary European political economy, as is widely recognized, faces a set of challenges that policy makers have tried to address through a mode of 'governance through financial markets,' amongst other things. As this paper has sought to demonstrate, this mode employs public development banks as anchor investors and promoters of market-based finance to do the institutional work necessary for 'making finance reach the real economy'. In this state-led mode of market-based finance, risk-sharing devices such as securitization and guarantees are keys for the governance through - and with and for - financial markets.

The policy framework for this endeavour can be found in the intricately linked Investment Plan for Europe and the Action Plan on Building a CMU. These plans do not seek to simply revert to the traditional bank-based loan business nor to the subsidized lending of development banks to achieve their goals. Instead, the initiatives embrace securitization and in its context the provision of guarantees and purchases of mezzanine and senior tranches. As such, the expansion of development bank activity operates within the framework of market-based finance, however, with a crucial modification. By focusing on the 'real economy' and its long-term financing needs, development banks seek to correct a shortcoming of market-based finance: its volatile and self-referential character. By collaborating across borders and on multiple levels of governance, these institutions use limited public funds to build an integrated infrastructure that tries to save finance from itself. Based on the rhetoric of market failure, these interventions serve the purpose of market-shaping. As such, they ease institutional investors' minds about specific asset classes through the provision of profitable investment opportunities for abundantly liquid financial markets. 
However, this sort of market-based finance, enabled by the state may have the potential to alter important characteristics of the current financial system and does not come without costs. First, the very mechanism of 'off-balance sheet policy making' is associated with a shift from democratic to technocratic rule over investment policy. While general policy objectives are still negotiated between democratically legitimated bodies, the material decisions concerning investment are taken in a less accountable and less transparent sphere, by experts within the EIB or NDBs. ${ }^{28}$ This seems to be the condition for a policy framework that is based on public guarantees; that needs to manage risks to limit costs as EU and national budgets provide some sort of fiscal backstop and that needs to provide return calculations to attract investors to information asymmetry-prone financial products. While this may lead to the often described depoliticization of public affairs (Wood, 2015), it may also fuel renewed political debate around the provision and pricing of toll services, as has been the case with a recent constitutional reform in Germany to restructure state responsibility for infrastructure and particularly motorways.

This newly created set-up we identify is not a neutral governance mechanism, and therefore has profound political implications. In this respect, the starkest warning regarding the risks of public-private partnerships that are conducted off-balance sheet and attempt to promote capital market development was revealed by the US experience with Fannie Mae and Freddie Mac after their privatization. As the US federal government wanted to pursue public policies with the help of private capital, the institutionalized set-up fed into a system where private investors' gains were insured by quasi-government guarantees, a system which the crisis turned into an emblematic case of privatizing profits and socializing losses. Within the orthodoxy of the 'consolidation state' such dangers remain real, even though the scope and institutionalization of the European practices we have delineated are still remote from this analogy. Nonetheless, in the next downturn, miscalculations may burden public budgets and the capacity for intervention of development banks when they are most needed, limiting their anticyclical capacities. Yet to fully understand such ambivalences involved in the increasingly visible role of development banks, to grasp its potentials and its pitfalls, our study can only serve as an initial step. As the Investment Plan is prolonged and CMU gradually moves forward, scholarship in European political economy, we think, should be on the watch.

\section{Acknowledgements}

We like to thank Oliver Kessler, Jamieson Myles, Sarah Quinn and Peter Volberding, the special issue editors as well as three anonymous reviewers for engaging and helpful comments.

\section{Authors' contribution}

Both authors contributed equally to this article.

\section{Declaration of Conflicting Interests}

The author(s) declared no potential conflicts of interest with respect to the research, authorship, and/or publication of this article.

\section{Funding}

The author(s) disclosed receipt of the following financial support for the research, authorship and/or publication of this article: Vanessa Endrejat and Jan Friedrich provided valuable research support. 


\section{Notes}

1. Video interview on http://ec.europa.eu/epsc/events/detail/2016-02-25-economic-diplomacy_en. htm, last accessed on 17 March 2016.

2. Instead of 'development banks', the EU policy context refers to 'promotional banks', which describes the very same institutions.

3. Investors are often called 'anchor investors' when they pursue a long-term strategy, adding value and attracting other investors through their reputation and capabilities, see Espenlaub et al. (2016); Hirshleifer and Hong (2003).

4. A list of interviewees is provided in the Appendix 1. These semi-structured interviews informed the direction and the discussion of the study, allowing us to both corroborate data from official documents and better understand the political intentions of policy makers and development bankers alike when formulating and implementing EFSI. However, they are not referenced in the analysis for the reconstruction of a narrative or a policy process, but only occasionally as additional data points.

5. STS stands for simple, transparent and standardized, a new format of securitization the European Commission seeks to install to re-establish the possibility for capital relief for banks using this financing technique (see Kraemer-Eis et al., 2015: 35ff).

6. Development banks can usually fund their activities with a similar rating as their public owners, which consequently is AAA for the EIB and the KfW, for instance, while the Spanish ICO for most of the past years borrowed on BBB conditions.

7. This notion is reinforced by policy initiatives that align increasing investment and reducing debt levels. For instance, in February 2015, the EC released a communication on 'making the best use of the flexibility within the existing rules of the Stability and Growth Pact' (European Commission, 2015c), clarifying how members' states and development banks could contribute to the Investment Plan without worsening their budgetary position with regard to the Pact. This was underlined by a 2016 fact sheet, explaining how governments should treat public-private partnerships statistically to comply with the Maastricht criteria (European Commission, 2016).

8. The rationale European policy makers have given for the EFSI correspondingly is that there 'is sufficient liquidity in the EU, but private investors are not investing at the levels needed due to a lack of confidence and uncertainty among other factors' (European Commission, 2015a: 1).

9. While the EIAH operates via the EIB, by May 2016 already 18 NDBs had signed a Memorandum of Understanding to contribute to the Hub, see europa.eu/rapid/attachment/IP-16-4024/en/EIAH \%20and\%20EIPP.pdf, last accessed on 10 December 2016.

10. See https://ec.europa.eu/info/business-economy-euro/growth-and-investment/capital-marketsunion/what-capital-markets-union_en, last accessed on 10 December 2017.

11. This again leads to the notion of excess liquidity in contemporary financial markets that need development banking to be 'used efficiently' through 'the channelling of such liquidity towards the funding of viable investment projects', as the EU regulation on the Investment Plan states, see European Union (2015: 2).

12. Toll goods, in contrast to public goods, introduce exclusion mechanisms to limit the access to public goods. One example is the introduction of highway fees for highways, thereby allowing only those able and willing to pay on the road.

13. In the wake of the Juncker Plan, development banks, first and foremost the EIB, have grown their personnel, hiring in particular experts on risk control. See https://luxtimes.lu/archives/383-thejuncker-plan-must-become-more-well-known, last accessed on 28 November 2017.

14. The EIF was founded in 1994 as a subsidiary of the EIB for the precise reason to attract more private funding both for large infrastructure projects, such as the Trans-European Networks, and for SMEs. The main tools at its disposal have been credit enhancement schemes based on securitization, venture capital and guarantees (Bussière et al., 2008: 222, 246).

15. https://ec.europa.eu/commission/priorities/jobs-growth-and-investment/investment-plan_en, last accessed on 19 July 2017. 
16. See http://eib.org/efsi/efsi-projects/index.htm, last accessed on 19 April 2017.

17. For the two latter see http://eif.org/what_we_do/efsi/guarantee-deals.pdf and http://www.eif.org/ what_we_do/efsi/equity-deals.pdf, last accessed on 19 April 2017.

18. The EC and EIB have used project bonds as examples of EFSI financing, such as the French Port of Calais infrastructure project, which entails subordinated debt by the EIB which is used to increase the quality of bonds worth roughly 500m EUR sold to the insurer Allianz. The underlying guarantee in this project had a leverage ratio of 1:60, and repayments were based on future fee income from the port and payments from the public sector. For both quotes above see http://eib. org/eib.org/products/blending/project-bonds/index.htm, last accessed on 25 July 2017.

19. Details on all projects mentioned can be obtained from the EIB project list website, see fn 16 .

20. EIB's EFSI financing here can take the form of a loan to the platform, a financial commitment (equity investment) in or through the platform, or a guarantee of loans given by the platform, so that the bank remains the anchor investor through the choice of projects and substance (European Commission and European Investment Bank, 2016).

21. The EFSI-related equity deals only reveal specialized funds participating, which in part have development banks as owners or investors, notably Bpifrance who focuses on equity markets.

22. As of 30 November 2017, 36.8\% of all credit guarantees allotted by the EIF under EFSI were granted to development banks, the largest ones to the Italian CDP, the German KfW and the Polish BGK, see http://eif.org/what_we_do/efsi/guarantee-deals.pdf, last accessed on 6 December 2017.

23. See www.eib.org/infocentre/events/all/seminar-on-synthetic-securitization-and-financial-guaran tees.htm, last accessed on 10 December 2017.

24. Using this technique, SME loans remain on the balance sheet of banks, which acquire a credit default swap from the development bank or the EIF (Ranne, 2005).

25. The program PROMISE issued its last SME securitization in 2008, as high percentage of nonperforming loans caused by the crisis and changes in the rating methodology made the market highly unattractive and led to an abstention by private investors (Kraemer-Eis et al., 2015: 21).The EIF, highly active in the years before 2009, would not undertake any securitization transaction in 2009 (Kraemer-Eis et al., 2015: 26).

26. Overall, the EIB Group's support to the European SME securitization market in 2015 and 2016 amounted to nearly EUR 8b, with EIB purchases of SME-related ABS of about $7 \mathrm{~b}$ and EIF guarantees for SME securitization of about 700m; see EIB and EIF (2017: 7-13).

27. In total, 8.8b Euros of EFSI financing were used for this purpose, related to an overall volume of investment of 69.5b Euros (European Investment Fund, 2017: 13).

28. This is despite the fact that Article 7 of the EFSI regulation obliges on high transparency standards as democratic control becomes also more difficult through the high degree of technicalities involved in governing through financial markets. See for further elaboration Ban and Seabrooke (2016).

\section{References}

Acharya VV, Eisert T, Eufinger C, et al. (2017) Whatever It Takes: The Real Effects of Unconventional Monetary Policy. Safe Working Paper 152, Frankfurt, pp. 1-50.

Acharya VV, Philippon T, Richardson MP, et al. (2009) The financial crisis of 2007-2009: Causes and remedies. In: VV Acharya and MP Richardson (eds) Restoring Financial Stability: How to Repair a Failed System. Hoboken, NJ: Wiley, pp. 1-56.

Baker A and Murphy R (2016) The coming crisis: Systemic stabilization and the investment state. Available at: http://speri.dept.shef.ac.uk/2016/05/18/thecomingcrisissystemicstabilizationandthein vestmentstate/ (accessed 23 March 2017).

Balser M (2017) Autobahn-Privatisierung erleidet herben Rückschlag [Harsh Blowback to Motorway Privatisation]. Süddeutsche Zeitung, 23 August. 
Ban C and Seabrooke L (2016) Investing in Integrity? Transparency and Accountability of the European Investment Bank. Brussels: Transparency International EU.

BBB, ICO, MDB Working Group, et al. (2016) ENSI: EIF and NPIs securitisation initiative. Enhanced co-operation to support SME securitisation in Europe. Luxembourg: European Investment Fund.

BPI, CDP, ICO, KFW (2015) SME investment and innovation: France, Germany, Italy and Spain. Paris: BPI France.

Braun B and Hübner M (2018) Fiscal fault, financial fix? Capital Markets Union and the quest for macroeconomic stabilisation in the Euro area. Competition \& Change.

Braun B, Gabor D and Hübner S (2018) Governing through financial markets: Towards a critical political economy of Capital Markets Union. Competition and Change.

Bussière É, Dumoulin M and Willaert É (2008) The Bank of the European Union. The EIB, 1958-2008. Luxembourg: Imprimerie centrale.

Callon M (2010) Performativity, misfires and politics. Journal of Cultural Economy 3(2): 163-169.

Counter Balance (2015) The New European Investment Plan. A Critical Analysis of Financial Instruments and Large Infrastructure Financing. Available at: http://www.counter-balance.org/ wp-content/uploads/2015/08/JP_A5_preview_Aug_2015_preview.pdf

Deeg R, Hardie I and Maxfield S (2016) What is patient capital, and where does it exist? SocioEconomic Review 14(4): 615-625.

Dorn N (2016) Capital cohabitation: EU Capital Markets Union as public and private co-regulation. Capital Markets Law Journal 11(1): 84.

Draghi M (2014) Keynote Speech at the Eurofi Financial Forum. Frankfurt am Main: European Central Bank Directorate General Communication.

EIB and EIF (2017) 2016 SME Report - EIB Group activities in support of SMEs and midcaps. Luxembourg: European Investment Fund.

Engelen E, Ertürk I, Froud J, et al. (2011) After the Great Complacence: Financial Crisis and the Politics of Reform. Oxford: Oxford University Press.

Engelen E and Glasmacher A (2018) The waiting game: Or, how securitization became the solution to the Eurozone's growth problem. Competition and Change.

Espenlaub S, Khurshed A, Mohamed A, et al. (2016) Committed anchor investment and IPO survival - The roles of cornerstone and strategic investors. Journal of Corporate Finance 41: 139-155.

European Commission (2004) Study on Asset-Backed Securities: Impact and Use of ABS on SME Finance. Brussels: Dictus Publishing.

European Commission (2014) An Investment Plan for Europe. COM(2014) 903. Available at: https:// ec.europa.eu/commission/sites/beta-political/files/investment_plan_booklet_en.pdf

European Commission (2015a) The Investment Plan for Europe: Questions and Answers. MEMO/15/ 5419. Available at: http://europa.eu/rapid/press-release_MEMO-15-5419_en.htm

European Commission (2015b) Working together for jobs and growth: The role of National Promotional Banks (NPBS) in supporting the Investment Plan for Europe. COM(2015) 361. Available at: http:// eur-lex.europa.eu/legal-content/EN/TXT/PDF/?uri $=$ CELEX:52015DC0012\&from $=\mathrm{EN}$.

European Commission (2015c) Making the best use of the flexibility within the existing rules of the stability and growth pact. COM(2015) 12.

European Commission (2015d) Action Plan on Building a Capital Markets Union. COM(2015) 468. Available at: http://eur-lex.europa.eu/legal-content/EN/TXT/PDF/? uri $=$ CELEX:52015DC0468\&from $=\mathrm{EN}$

European Commission (2016) Launch of the EPEC-Eurostat Guide to the Statistical Treatment of Public-Private Partnerships. MEMO/16/3224. Brussels: EIB Press.

European Commission (2017a) Remarks on the progress of the Capital Markets Union. Available at: https://ec.europa.eu/commission/commissioners/2014-2019/katainen/announcements/remarksprogress-capital-markets-union_en 
European Commission (2017b) Completing the Capital Markets Union: Building on the first round of achievements. Press Release IP/17/1529. Available at: http://europa.eu/rapid/press-release_IP-171529_en.htm

European Investment Fund (2017) Annual Report 2016. Luxembourg: European Investment Fund Press.

European Union (2015) Regulation (EU) 2015/1017 of the European Parliament and of the Council of 25 June 2015 on the European Fund for Strategic Investments, the European Investment Advisory Hub and the European Investment Project Portal.

Friedrich JM and Thiemann (2017) Capital Markets Union: The need for common laws and common supervision. Vierteljahrshefte zur Wirtschaftsforschung 86(2): 61-75.

G20 (2017) Leaders' Declaration: Shaping an interconnected world. Hamburg: Consilium.

Gabor D and Verstergaard J (2018) Chasing unicorns: The European single safe asset project. Competition and Change.

Griffith-Jones S and Cozzi G (2016) Investment-led growth: A solution to the European crisis. In: M Mazzucato and M Jacobs (eds) Rethinking Capitalism: Economic Policy for Sustainable and Equitable Growth. Hoboken: Wiley-Blackwell.

Hardie I, Howarth D, Maxfield S, et al. (2013) Banks and the false dichotomy in the comparative political economy of finance. World Politics 65(4): 691-728.

Helleiner E (1994) States and the Reemergence of Global Finance. From Bretton Woods to the 1990s. Ithaca/London: Cornell University Press.

Hill J (2015) A brave new world for banks. In: Speech at European Banking Federation, 2015 annual high level conference. Brussels.

Hirshleifer D and Hong TS (2003) Herd behaviour and cascading in capital markets: A review and synthesis. European Financial Management 9(1): 25-66.

Hood C (1991) A public management for all seasons? Public Administration 69(1): 3-19.

House of Commons, Environmental Audit Committee (2011) The Green Investment Bank: Second Report of Session 2010-11. London: The Stationery Office Limited.

Hübner M (2016) Securitisation to the Rescue. The European Capital Markets Union Project, the Euro Crisis and the ECB as 'Macroeconomic Stabilizer of Last Resort'. Brussels: FEPS STUDIES.

Inderst G (2013) Private Infrastructure Finance and Investment in Europe. Working Papers 2013/02, EIB, Luxembourg.

Joint Committee of the European Supervisory Authorities (2017) Joint Committee Report on Risks and Vulnerabilities in the EU Financial System.

Kollatz-Ahnen M (2015) The rise of state investment banks. In: M Mazzucato and CC Penna (eds) Mission-Oriented Finance for Innovation. New Ideas for Investment-Led Growth. London, New York: Rowman \& Littlefield, pp.111-118.

Konings M (2011) The Development of American Finance. Cambridge: Cambridge University Press.

Kraemer-Eis H, Passaris G and Tappi A (2013) SME Loan Securitisation 2.0: Market Assessment and Policy Options. Working Paper 2013/19, EIF, Luxembourg.

Kraemer-Eis H, Passaris G, Tappi A, et al. (2015) SME Securitisation - at A Crossroads? Working Paper 2015/31, EIF, Luxembourg.

Langfield S and Pagano M (2016) Bank bias in Europe: Effects on systemic risk and growth. Economic Policy 31(85): 51-106.

Mazzucato M and Penna CC (2016) Beyond market failures: The market creating and shaping roles of state investment banks. Journal of Economic Policy Reform 19(4): 305-326.

Mertens D (2017) Borrowing for social security? Credit, asset-based welfare and the decline of the German savings regime. Journal of European Social Policy 27(5): 474-490.

Mertens D and Thiemann M (2017) Building an investment state? The European Investment Bank, national development banks and European economic governance. Journal of European Public Policy (online first). 
Moss DA (2002) When All Else Fails. Government as the Ultimate Risk Manager. Cambridge, London: Harvard University Press.

OECD (2014) Private Financing and Government Support to Promote Long-term Investments in Infrastructure. Paris: OECD.

OECD (2015) OECD Business and Finance Outlook 2015. Paris: OECD Publishing.

Palley TI (2013) Financialization: The Economics of Finance Capital Domination. Basingstoke: Palgrave Macmillan.

Polanyi K (1944) The Great Transformation. Boston: Beacon Press.

Quaglia L, Howarth D and Liebe M (2016) The political economy of European Capital Markets Union. Journal of Common Market Studies 54(S1): 185-203.

Quinn S (2017) 'The Miracles of Bookkeeping': How budget politics link fiscal policies and financial markets. American Journal of Sociology 123(1): 48-85.

Ranne O (2005) Kreditverbriefung und Mittelstandsfinanzierung [Securitisation and SME Finance]. Beiträge Zur Mittelstands- Und Strukturpolitik 33: 43-66.

Rubio E, Rinaldi D and Pellerin-Carlin T (2016) Investment in Europe: Making the Best of the Juncker Plan. Jacque Delors Institute Studies and Reports 109, Paris, Berlin.

Streeck W (2015) The Rise of the European Consolidation State. In: Magara H (ed.) Policy Change Under New Democratic Capitalism. London and New York: Routledge, pp. 27-46.

Thiemann M, Birk M and Friedrich J (2018) Much ado about nothing? Macro-prudential ideas and the post-crisis regulation of shadow banking. Koelner Zeitschrift Fuer Soziologie Und Sozialpsychologie 70(1): 52-77.

Verdier D (2000) The rise and fall of state banking in OECD countries. Comparative Political Studies 33(3): 283-318.

Verdun A (2015) A historical institutionalist explanation of the EU's responses to the euro area financial crisis. Journal of European Public Policy 22(2): 219-237.

Véron N and Wolff GB (2016) Capital Markets Union: A vision for the long term. Journal of Financial Regulation 2(1): 130-153.

Wood M (2015) Puzzling and powering in policy paradigm shifts: Politicization, depoliticization and social learning. Critical Policy Studies 9(1): 2-21.

Wruuck P (2016) Promoting Investment in Europe: Where Do We Stand with the Juncker Plan? Frankfurt: Deutsche Bank Research.

Zysman J (1983) Governments, Markets, and Growth. Financial Systems and the Politics of Industrial Change. Oxford: Martin Robertson.

\section{Appendix I. List of interviewees}

\begin{tabular}{llll}
\hline I & KFW official & 23 March 20I5 & Frankfurt/Main \\
2 & NGO official, EIB expert & I8 May 2016 & Brussels \\
3 & KFW official & 24 May 2016 & Frankfurt/Main \\
4 & Former EC official & 27 May 2016 & Berlin \\
5 & EIF officials & 8 June 2016 & Luxembourg \\
6 & MEP/ECON member & 20 June 2016 & Brussels \\
7 & KFW official & 22 June 2016 & Frankfurt/Main \\
8 & EIB official & 6 July 2016 & Luxembourg \\
9 & KfW official & I August 2016 & Brussels \\
10 & Former EIB official & 2 August 2016 & Luxembourg \\
II & Former EIB official & 29 September 2016 & Berlin \\
\hline
\end{tabular}

